\title{
INSPECTING PRIMARY HEALTHCARE CENTERS IN REMOTE AREAS: FACILITIES, ACTIVITIES, AND FINANCES
}

\author{
Menilik Puskesmas di Daerah Tertinggal: Kepatutan, Kegiatan, dan Keuangan
}

\author{
Prastuti Soewondo ${ }^{1}$, Meliyanni Johar ${ }^{2}$, ${ }^{*}$ Retno Pujisubekti ${ }^{3}$, Halimah ${ }^{4}$, Dwi Oktiana Irawati ${ }^{5}$ \\ 1,2,3,4,5Team for Health Insurance Policy, National Team for the Acceleration of Poverty Reduction, Indonesia \\ ${ }^{1}$ Faculty of Public Health, University of Indonesia, Indonesia \\ ${ }^{*}$ Correspondence: retno.pujisubekti@tnp2k.go.id
}

\begin{abstract}
Background: Progress towards health-for-all must be supported by quality health facilities that are available to everyone. However, healthcare facilities in remote and underdeveloped areas, borderlands, and outlying islands, or daerah terpencil, tertinggal, perbatasan dan kepulauan (DTPK), face constraints regarding access to health coverage.

Aim: This study aims to provide a comprehensive picture of the readiness of primary healthcare centers or puskesmas as the main provider of primary health services located in remote areas.

Methods: Observations were made within 18 primary healthcare centers in locations that had been identified as remote and underdeveloped areas, borderlands, and outlying islands in three provinces: Bengkulu, Nusa Tenggara Timur (East Nusa Tenggara), and South Sulawesi.

Results: The findings revealed that many facilities in primary healthcare centers remain insufficient. In particular, roads to primary healthcare centers are in poor physical condition, operational hours are too short, and doctors and laboratory technicians are unavailable. However, primary healthcare centers have managed to conduct many indoor and outdoor activities such as health education classes and the detection of priority diseases within the community. Regarding the finances of primary healthcare centers, they largely depend on public funding to support their increasing expenses to provide health services, pay worker salaries, and conduct indoor and outdoor activities.

Conclusions: Overall, some constraints faced by the primary healthcare centers in DTPK include difficult access to facilities and temporary health personnel. This information provides valuable input to policymakers in building health infrastructure and human resources for health in DTPK.
\end{abstract}

Keywords: remote area, human resources for health, primary healthcare center

Received: 27 September $2018 \quad$ Accepted: 2 January $2019 \quad$ Published: 15 April 2019

\section{INTRODUCTION}

In Indonesia, a primary healthcare center, or puskesmas, is the first-level (primary) health facility under the district health office that is responsible for the health of the people living in its jurisdiction. As a primary health facility, a primary healthcare center is where patients and health personnel often meet for the first time and interact with each other to consult about health problems, check vital health conditions, receive medications, and obtain useful health information, health-enhancing advice, and referrals to complementary health services. Primary healthcare centers also act as gatekeepers to higher-level facilities such as hospitals and specialized clinics. In 2017, 9,825 primary healthcare centers operated throughout the country (Kurniawan, Yudianto, Hardhana, and Siswanti, 2018), with at least one primary healthcare center in every district.

In this study, the conditions of primary healthcare centers in remote areas are analyzed using several pertinent questions. Are primary healthcare centers in these areas sufficiently equipped to meet the primary care needs of the people living in their territory? Have they managed to reach everyone through their outdoor activities? Alternatively, do they make any effort at all to engage with the local community? What has been the status of their finances over the past few months? Has there been any significant increase in primary healthcare centers' revenues or expenses? The answers to these questions can serve as valuable inputs to policymakers to enable the provisioning of highquality primary healthcare, especially in remote areas, where the private health sector tends to be unprofitable, and the health of residents relies heavily on the readiness of the public sector.

There is a dearth of published, scientific literature on primary healthcare centers. The few existing studies are limited in scope, only sampling patients from one-to-three primary healthcare centers to investigate patient satisfaction regarding the services they received. Utama, Lestari, and Ikmaluhakim (2017) conducted a study in a primary healthcare center in Ngagel Rejo, Surabaya that could accommodate up to 100 patients a day. Their study found patient satisfaction to be quite low regarding the cleanliness and comfort of the waiting 
room and the responsiveness of the staff at registration desks. At other primary healthcare centers, Biyanda et al. (2017) found that patients were quite satisfied with facility conditions, but were dissatisfied with how doctors addressed their health complaints, judging them as lacking compassion, empathy, accuracy, and attention to detail. An important consideration is that if a patient has a bad experience in primary healthcare centers, it may discourage repeat visits (Afifah, 2017). Apriyanto, Kuntjoro, and Lazuardi (2013) interviewed 111 patients in three primary healthcare centers in Singkawang, West Kalimantan, and found that patients awarded a score of approximately 2.5 (from a 5-point scale) for every dimension of services they required. These dimensions ranged from the quality of the health services in general to the punctuality of operating hours. Different from the three studies noted above, Djauhari (2010) investigated important inputs that contributed to the provisioning of highquality services in primary healthcare centers. The author found financial input as being the most critical, followed by the structure of bureaucracy, the availability of health resources, and finally, communication. There are additional student dissertations and articles on specific programs in primary healthcare centers, but these are not published in scholarly journals (see, e.g., Vondewi, 2010; Putra, 2012). To the best of our knowledge, there is to date no literature on primary healthcare centers in Indonesian remote areas.

Three studies that closely match ours are those of Sagala, Trisnantoro, and Padmawati (2016), Husain, (2006), and Suharmiati, Handayani, and Kristiana (2012). Sagala, Trisnantoro, and Padmawati inspected the provisioning of health services at Kepulauan Anambas, one of the so-called remote and underdeveloped areas, borderland, and outlying islands, or daerah terpencil, tertinggal, perbatasan dan kepulauan (DTPK) in Riau province; however, their research focused on a hospital context. Husain (2006) used data from primary healthcare centers and auxiliary primary healthcare centers, or puskesmas pembantu (pustu), in a survey of Indonesian family life, or Survei Aspek Kehidupan Keluarga Indonesia (sakerti), fielded in 13 provinces. Comparing conditions of primary healthcare centers in rural and urban areas, the study found that doctor availability in urban primary healthcare centers was much higher than that in their rural counterparts, particularly in Java, Bali, and the Sumatra islands. However, the availability of paramedics in rural primary healthcare centers was found to be quite good. While this study highlighted the geographical differences in human resources for health, it was not comprehensive. Furthermore, the Sakerti data used in the study were quite old, having been collated almost two decades ago.

More recently, Suharmiati, Handayani, and Kristiana (2012), and Suharmiati, Laksono, and Astuti (2013) collected data from a primary healthcare center in Sajingan Besar, a remote area in West Kalimantan province, to investigate factors that influence access to facilities. They found a severe lack in the availability of human health resources, indicating that primary healthcare centers were unable to conduct a range of activities, particularly outdoor events. Medical equipment, medical supplies, and drug supplies were also restricted. In terms of patient access to primary healthcare centers, they found transportation to be the biggest hurdle. However, the findings of this study were only based on the experience of one primary healthcare center. It would be interesting to inspect several centers in remote areas and include many more dimensions of service provisioning in addition to human resources for health and access barriers for patients.

In the current study, the researchers visited 18 primary healthcare centers in national health target locations included into the Nusantara Sehat (NS) program, initiated by the Ministry of Health Indonesia. A team of health personnel comprising doctors, dentists, nurses, public health experts, environmental health experts, laboratory technicians, nutritionists, and pharmacists went to areas deemed as remote and underdeveloped, borderlands, and outlying islands that lacked human resources for health. At these facilities, the researchers interviewed the managers of these primary healthcare centers to obtain information about their facility conditions, activities inside and outside of the centers, and any changes to their finances in recent months.

Our inspection found that access to primary care in remote and underdeveloped areas, borderlands, and outlying islands remain challenging, with roads to primary healthcare centers often in poor physical condition (e.g., many potholes, rocky, and not asphalted). Furthermore, healthcare centers lacked permanent doctors and laboratory facilities (or laboratory technicians) to conduct blood tests. In terms of activities conducted by primary healthcare centers, the current study found that most had been quite active in delivering outdoor programs, engaging in preventive and promotive activities such as detecting cases of priority diseases (e.g., hypertension, diarrhea, and malnourishment among young children) in the community and presenting health education classes. Primary healthcare centers also initiated and monthly monitored integrated health service posts (Posyandu), integrated village noncommunicable disease (NCD) prevention posts for the elderly (Posbindu Lanjut Usia/Lansia), and integrated village NCD prevention posts for noncommunicable diseases (Posbindu PTM/Penyakit Tidak Menular). Finally, concerning financial conditions, the current study found that both income and expenses had increased, and very few healthcare centers spent money on the refurbishment of facilities.

\section{METHODS}

The current research is a qualitative study that was conducted using in-depth interviews at the primary healthcare center level. Healthcare centers were chosen based on the results of a purposive sampling technique. The researchers developed the survey instruments (in the Indonesian language), which included activities in primary healthcare centers, patient volumes, the available facilities of healthcare centers, of the required medical equipment and medical supplies, human resources for health, indoor and outdoor activities, and changes to centers' 
revenues and expenses. The aim of gathering this information was to provide knowledge on three dimensions of primary healthcare centers: the level (or quality) of facilities inside and in the vicinity of the primary healthcare center building, currently running activities, and changes in finances in recent months. The researchers pilot-tested the survey instrument on the personnel of several primary healthcare centers in a DTPK in Lampung province (nearest to Jakarta) and revised the survey instrument accordingly.

Table 1. The locations and participants of sampled primary healthcare centers.

\begin{tabular}{|c|c|c|c|c|c|}
\hline Province & District & $\begin{array}{c}\text { Area } \\
\text { Size } \\
\left(\mathrm{km}^{2}\right)\end{array}$ & \#Villages & \# People & Informants \\
\hline \multirow[t]{6}{*}{ Bengkulu } & Sekayun & 79.00 & 11 & 6,968 & Head of administration \\
\hline & Ketenong & 63.09 & 8 & 4,840 & Head of the primary healthcare center \\
\hline & Tanjung Harapan & 24.30 & 10 & 11,451 & Head of the primary healthcare center \\
\hline & Pagar Jati & 70.00 & 10 & 5,892 & $\begin{array}{l}\text { Acting head of primary healthcare } \\
\text { center }\end{array}$ \\
\hline & Taba Teret & 96.00 & 7 & 5,696 & Head of administration \\
\hline & Taba Lagan & 50.00 & 9 & 7,029 & Head of administration \\
\hline \multirow{6}{*}{$\begin{array}{l}\text { South } \\
\text { Sulawesi }\end{array}$} & Kondodewata & 196.74 & 17 & 30,691 & Head midwife \\
\hline & Rampi & 156.56 & 7 & 3,134 & Head of the primary healthcare center \\
\hline & Latimojong & NA & 12 & 26,819 & Head of administration \\
\hline & Walenrang Barat & NA & 6 & 10,716 & Head of the primary healthcare center \\
\hline & Bittuang & 134.47 & 13 & 19,550 & Head of the primary healthcare center \\
\hline & Rano & 166.02 & 6 & 6,119 & General practitioner \\
\hline East Nusa & Ngalupulo & 106.47 & 13 & 13,169 & Head of the primary healthcare center \\
\hline Tenggara & Watuneso & 46.79 & 12 & 8,613 & Head of the primary healthcare center \\
\hline \multirow[t]{4}{*}{ (NTT) } & Iteng & 138.00 & 10 & 16,671 & Head of administration \\
\hline & Beamese & 226.10 & 7 & 9,681 & $\begin{array}{l}\text { Acting head of primary healthcare } \\
\text { center }\end{array}$ \\
\hline & Ranggu & 30.44 & 8 & 8,713 & Head of operation \\
\hline & Pacar & 63.50 & 12 & 14,066 & Head of the primary healthcare center \\
\hline
\end{tabular}

With their available budget, the researchers chose DTPKs in three provinces, which included West to East Indonesia: Bengkulu, South Sulawesi, and East Nusa Tenggara. It is well-documented that health conditions and health supply levels vary significantly across Indonesian regions, with East Indonesia faring the worst compared to other regions (Kurniawan, Yudianto, Hardhana, and Siswanti, 2018; Worldbank, 2018). The data collection received ethical approval from Gajah Mada University (REF No. KE/FK/0510/EC/2018) and an implementation permit from the Vice President's Office of the Executive Secretary of the National Team for the Acceleration of Poverty Reduction.

In each province, six DTPK districts were visited, with one primary healthcare center per district, giving a total of 18 . These primary healthcare centers included six to 17 villages, with populations of between 3,000 and 30,000 (Ministry of Health of the Republic Indonesia, 2017b, 2017c, 2017d). Compared to other primary healthcare centers in the districts, they had a relatively tolerable communication infrastructure (paved roads, internet connection, and electricity), allowing for a smooth data collection process. In addition, they included many households in their catchment area (territory), enabling a more accurate picture of the various services provided by primary healthcare centers. The main information sources of this study were the managers of primary healthcare centers, who were likely to be the most knowledgeable about the conditions and activities inside the facility and their outreach programs to local communities. When the head of a primary healthcare center was not available, the head of administration, the head of operations, acting head, or a senior health worker in charge became the informant. The interviews were led by experienced interviewers using electronic tablets and each interview lasted approximately 1.5 hours. Table 1 shows the districts of the sampled primary healthcare centers and the informant at each primary healthcare center.

\section{RESULTS AND DISCUSSION}

Table 2 indicates the facilities in primary healthcare centers, including operating hours, ease of access for patients, level of available human resources for health, available rooms, and the adequacy of medical equipment and medical supplies. The researchers reported findings from all primary healthcare centers in the sample (and by province) to highlight the regional variations in health supply.

Ten primary healthcare centers in the sample had beds for inpatient care (inpatient primary healthcare centers), while eight primary healthcare centers had no beds for non-inpatient care (outpatient 
primary healthcare centers). Half of the primary healthcare centers with inpatient beds were located in East Nusa Tenggara (NTT). In Bengkulu, only one among the six primary healthcare centers visited could provide inpatient services.

All primary healthcare centers in the sample were open Monday to Saturday. Four were also open on Sundays, of which three had beds. The operating duration was four-to-six hours a day, between 7:00$8.00 \mathrm{am}$ to $12: 00-14.00 \mathrm{pm}$. This format applied in most primary healthcare centers throughout the country, not only to those located in DTPK. Most patients used a private vehicle or public motorbike to attend primary healthcare centers. However, the roads to primary healthcare centers were often in poor physical condition, e.g., not asphalted, full of potholes, flooded, and rocky. Furthermore, many patients needed to traverse rivers (12 primary healthcare centers) and valleys (15 primary healthcare centers) to reach healthcare centers. On average, it took patients 99 minutes to reach a primary healthcare center; for some, however, travel time could reach six hours (primary healthcare centers in Rampi, South Sulawesi). These access barriers reflect conditions at DTPKs that are remote with inferior transportation infrastructures.

Table 2. Operating hours, human resources, and amenities in 18 primary healthcare centers by province.

\begin{tabular}{lllll}
\hline & Bengkulu & NTT & South Sulawesi & Total \\
\hline \# Primary healthcare centers & 6 & 6 & 6 & 18 \\
\# Inpatient primary healthcare centers & 1 & 5 & 4 & 10 \\
Operating hours & & & & 18 \\
\# Open Monday-Saturday & 6 & 6 & 6 & 4 \\
\# Open Sunday & 1 & 2 & 1 & 5.58 hours \\
Average duration (Monday-Thursday) & 5.8 hours & 5.1 hours & 5.9 hours & 4.04 hours \\
Average duration (Friday) & 3.9 hours & 3.1 hours & 5.2 hours & 4.75 hours \\
Average duration (Saturday) & 4.8 hours & 3.8 hours & 5.6 hours & Private \\
Mode of arrival & Private & Public & Public & Rp.51,000 \\
Average transport cost & Rp.13,000 & Rp.29,000 & Rp.104,100 & 99 minutes \\
Average travel time & 43 minutes & 140 minutes & 143 minutes & \\
Average per Primary healthcare & & & & 0.89 \\
center & & & & 0.39 \\
General practitioner (GP) & 1.5 & 0.5 & 0.67 & 14 \\
Dentist & 0.33 & 0.33 & 0.5 & 17.4 \\
Nurse & 10.8 & 22.3 & 8.8 & 0.78 \\
Midwife & 15.3 & 22.7 & 14.2 & 1.11 \\
Pharmacist & 0.67 & 1.17 & 0.5 & 1.17 \\
Nutritionist & 0.33 & 2 & 1 & 0.89 \\
Public health expert & 1.67 & 0.83 & 1 & 0.39 \\
Environmental health expert & 0 & 1.67 & 1 & 3.94 \\
Lab technician & 0 & 1.17 & 0 & 16 \\
Average \# consultation rooms & 3.33 & 5.17 & 3.33 & 10 \\
\# with a storage room for drugs & 6 & 6 & 4 & 2 \\
\# with a laboratory & 2 & 5 & 3 & 4 \\
\# with availability "none"l "very poor" & 2 & 0 & 0 & \\
Variety of drugs & 2 & 0 & 1 & \\
Medical supplies & 1 & 0 & & \\
Medical equipment & 3 & & & \\
\hline
\end{tabular}

On average, the primary healthcare centers in the sample had 0.89 general practitioners (GPs), 0.39 dentists, 14 nurses, and 17 midwives. Having less than one doctor in a primary healthcare center meant that some centers had no permanent doctor. The researchers identified five primary healthcare centers (three in NTT and two in South Sulawesi) that did not have a permanent GP and 11 that did not have a permanent dentist. This fell short of the minimum standard human resources for health according to the Ministry of Health's decree, or Permenkes number 75, 2014 (75/2014) about primary healthcare centers, which states that for remote and very remote areas, there should be one GP in an outpatient primary healthcare center, two GPs in an inpatient primary healthcare center, and one dentist at every outpatient primary healthcare center (Ministry of Health of the Republic Indonesia, 2014b). The absence of a doctor may in turn discourage people from seeking health treatment in primary healthcare centers, keeping in mind that reaching these centers is not easy for many, particularly for those who live far away. The minimum standard also requires a minimum of five nurses and four midwives in an outpatient primary healthcare center, and eight nurses and seven midwives in an inpatient primary healthcare center (Ministry of Health of the Republic Indonesia, 2014b).

Similarly, the unavailability of a pharmacist and a lab technician in primary healthcare centers means they cannot dispense doctor prescriptions or conduct blood tests. According to the Ministry of Health's decree number $75 / 2014$, there should be a laboratory technician, pharmacist, public health expert, and environmental health expert at each outpatient primary healthcare center and inpatient primary healthcare center, a nutritionist in every outpatient primary healthcare center, and two nutritionists at every inpatient primary healthcare 
center (Ministry of Health of the Republic Indonesia, 2014b).

Most primary healthcare centers in the sample had at least three consultation rooms and a room in which to store drugs (16 primary healthcare centers). However, only 10 had a functioning laboratory, two had a laboratory that was in a poor physical condition, while eight had no laboratory. The availability of medical equipment (such as stethoscopes, thermometers, body scales, and sphygmomanometers to measure blood pressure) and medical supplies (such as cotton balls, syringes, and medical plasters) appeared to have been quite good. Few primary healthcare centers in the sample reported that these medical essentials were either unavailable or only available in unacceptable numbers. There were also very few complaints about the variety of drugs supplied to primary healthcare centers.

Table 3 presents activities in primary healthcare centers and shows that 15 of the 18 primary healthcare centers in the sample used computers to conduct administrative tasks and keep patient records. Moreover, despite being located in DTPK, primary healthcare centers nonetheless strived for efficiency and were committed to having accurate records of their patients and activities. This finding should ease many speculations that administrative data in primary healthcare centers in remote or rural areas are messy and unreliable. Policymakers can already use these records to oversee the daily activities of centers, their human resources, finances, the services they provide to publicly-insured patients, and to track the prevalence of common diseases in the community. The use of computer systems also aids regular monitoring and evaluation processes.

In one month, primary healthcare centers treated 481 outpatient cases and 12 inpatient cases (in 10 inpatient primary healthcare centers), or approximately 25 patients per day. Outside the DTPK area, a typical primary healthcare center could on average receive $90-100$ patients per day (Rizcarachmakurnia, Wigati, and Sriatmi, 2017; Utama, Lestari, and Ikmaluhakim, 2017). Furthermore, there were more female than male patients, a trend also observed elsewhere (Rahmayanti and Ariguntar, 2017). Almost $70 \%$ of cases were provided to contribution beneficiaries grantees (Penerima Bantuan luran [PBI]), whose insurance premiums were paid by the government. In larger cities, a larger number of general patients may be paying "out-of-pocket", but the majority of patients are covered by public insurance (PT Iconesia Solusi Prioritas, 2016). Primary healthcare centers in DTPK can manage most patient presentations, with approximately $6 \%$ referral rates to higher-level health facilities (hospitals). Aside from cases requiring more advanced medical treatment, referrals may also be caused by a shortage of medicine, inadequate medical equipment, and practical distance to the nearest higher-level facility (Alawi, Junadi and Latifah, 2017). The most common health problems presented were acute and communicable diseases. Twelve primary healthcare centers reported upper respiratory tract infection (ISPA) as the disease with the highest occurrence. This finding was also the case elsewhere, not only in primary healthcare centers in DTPK (Afifah, 2017; Firnanda N, Junaid, and Jafriati, 2017; Rahmayanti and Ariguntar, 2017; Indonesian Ministry of Health, 2014). In addition to ISPA, primary healthcare centers also observed many instances of chronic disease, particularly hypertension and chronic digestive disorders (Rahmayanti and Ariguntar, 2017). Indeed, the prevalence of chronic diseases is predicted to increase in the coming decades, based on an aging population a shift towards sedentary lifestyles and unhealthy diets (Institute for Health Metrics and Evaluation, 2018; Indonesian Ministry of Health, 2014).

All primary healthcare centers in the sample presented health education classes, with topics including the promotion of clean and healthy lifestyles (such as the habit of washing hands with soap before eating and preparing meals, staying active every day, smoking cessation, and following a diet containing plenty of fruits and vegetables). These classes also included an introduction to the symptoms, causes, and treatments of common diseases, and motherand-children health-related information such as antenatal care, common problems during pregnancy, exclusive breastfeeding in the first six months, and the benefits of immunization. The most frequently presented classes were on the promotion of a clean and healthy lifestyle and its links with the prevention of communicable diseases such as diarrhea and tuberculosis, and its impact on children's health. As health awareness increases, people may be more likely to visit primary healthcare centers to obtain health treatment, medical advice, or regular health check-ups (Napirah, Rahman, and Tony, 2016). Among the three provinces in the sample, primary healthcare centers in NTT appear to be the most active regarding educational classes.

Most primary healthcare centers in the sample had extended their reach outdoors into the local community to detect the prevalence of priority diseases such as hypertension, tuberculosis, and malnourishment among young children. The most intensely monitored health problems were hypertension, malnourishment (stunting and wasting) in children below the age of five years, and receiving complete primary immunization. As in the case of educational classes, outdoor detection programs were managed most intensively by primary healthcare centers in NTT.

Primary healthcare centers are responsible for forming and overseeing posyandu in their catchment area. On average, the primary healthcare centers in the sample oversaw 16 active posyandu, which were presented monthly. Most primary healthcare centers also initiated monthly posbindu lansia and posbindu PTM.

These findings on the outdoor activities of primary healthcare centers differ from findings in Suharmiati, Handayani, and Kristiana (2012), who found that the lack of health workers in primary healthcare centers prevented them from conducting outdoor activities. One potential explanation for this may be that the catchment area of most primary healthcare centers in our sample was much wider 
compared with the noted study and the latter's population had been small and sparsely distributed.

To elicit information about financial circumstances, the informants were asked whether (compared to the preceding three months) income, the absorption of funds, and expenses had increased (and by how much), remained stable, or had decreased (and by how much). Since changes tend to be polarized towards extremes (increased or decreased significantly), the researchers pooled together answers indicated an increase (">") and decrease ("<"). Table 4 presents the results of this question.

Table 3. Activities in primary healthcare centers.

\begin{tabular}{|c|c|c|c|c|}
\hline & Bengkulu & NTT & South Sulawesi & Total \\
\hline $\begin{array}{l}\text { \# Primary healthcare centers } \\
\text { \# with a computerized administrative }\end{array}$ & 6 & 6 & 6 & 18 \\
\hline $\begin{array}{l}\text { system } \\
\text { Average case (monthly^) }\end{array}$ & 4 & 6 & 5 & 15 \\
\hline Outpatient females & 134.5 & 471.8 & 257.9 & 288.1 \\
\hline Outpatient males & 155.4 & 239.4 & 185.0 & 193.3 \\
\hline Outpatient total & 274.6 & 711.2 & 448.3 & 481.3 \\
\hline Inpatient females & 5.7 & 11.7 & 5.3 & 7.9 \\
\hline Inpatient males & 5.0 & 4.8 & 2.7 & 3.8 \\
\hline Inpatient total & 10.7 & 16.4 & 8.1 & 11.7 \\
\hline Outpatient PBIs & 250.3 & 467.3 & 253.4 & 337.9 \\
\hline Inpatient PBls & 6.3 & 8.2 & 6.6 & 7.3 \\
\hline Average referral rates (\%) & 0.09 & 0.04 & 0.05 & 0.06 \\
\hline Average $\%$ cases from $\mathrm{PBI}$ & 0.62 & 0.69 & 0.73 & 0.68 \\
\hline Cases with the highest volume 1 & ISPA & ISPA & ISPA & ISPA \\
\hline Cases with the highest volume 2 & Hypertension & Musculoskeletal & Digestive & Hypertension \\
\hline Cases with the highest volume 3 & Digestive & Digestive & Hypertension & Digestive \\
\hline $\begin{array}{l}\text { \# can handle all cases } \\
\text { \# with education classes }\end{array}$ & 5 & 6 & 5 & 16 \\
\hline Diarrhea and a clean and healthy lifestyle & 5 & 6 & 5 & 16 \\
\hline The habit of handwashing at school & 5 & 5 & 3 & 13 \\
\hline Introduction about hypertension & 6 & 6 & 5 & 17 \\
\hline Introduction about tuberculosis & 5 & 5 & 3 & 13 \\
\hline Importance of exclusive breastfeeding & 6 & 6 & 5 & 17 \\
\hline $\begin{array}{l}\text { Information on children's health } \\
\text { \# with outdoor detection programs }\end{array}$ & 5 & 6 & 5 & 16 \\
\hline Hypertension & 5 & 6 & 5 & 16 \\
\hline Tuberculosis & 5 & 6 & 4 & 15 \\
\hline Malnutrition below the age of 5 years & 4 & 5 & 4 & 13 \\
\hline Average active Posyandu & 11.2 & 23.3 & 15.2 & 16.6 \\
\hline \# with Posbindu PTM & 6 & 4 & 4 & 14 \\
\hline \# with Posbindu Lansia & 5 & 6 & 1 & 12 \\
\hline
\end{tabular}

Note: \# number of observations; ^ monthly average was obtained from quarterly data divided by three.

In the past three months preeciding the research, 14 of the 18 primary healthcare centers in the sample reported having received increased funding from the central government through health operational grants or Bantuan Operasional Kesehatan (BOK). Funding from public insurance (JKN capitation fund) increased in six primary healthcare centers, while revenues from out-of-pocket patients in most primary healthcare centers were relatively stable or in decline. This trend reflected an increase in the number of publicly-insured patients in primary healthcare centers, which in turn reduced the number of general patients. As such, this trend also suggests that centers are increasingly dependent on public funding as their primary source of income.

Absorption of funds essentially followed on from the increased funding. For example, the BOK fund is absorbed by increases in daily operational activities, following the presence of a higher patient volume. Furthermore, workloads increased alongside the higher number of patients that presented in primary healthcare centers. This situation was echoed by the Ministry of Health (Ministry of Health of the Republic of Indonesia, 2017a).

Thirteen of the 18 primary healthcare centers in the sample reported increased expenses for medical service provisions, while only seven reported increased expenses for paying health personnel. With capitation funding, it is imperative to re-adjust worker compensation, given the increases in patient volume (Ramdani, Setiawati, and Herawati, 2016; KOMPAK, 2017). Ten primary healthcare centers reported increased expenses due to increases in indoor activities, and 12 reported increased expenses due to outdoor activities. Only three primary healthcare centers increased spending on building facilities; most provided either a "not relevant" or "do not know" answer to this question.

In conclusion, several shortcomings in facilities require urgent attention. For example, short operating hours and early closing times (12.00 am) render obtaining treatment non-feasible for many. 
This includes patients who work long hours without sick permits or leave (e.g., blue-collar workers and farmers). Primary healthcare centers should consider running afternoon sessions, e.g., opening again at 14.30 to 17.30 (PT Iconesia Solusi Prioritas, 2016). Similar complaints were also documented by Apriyanto (2016) and Juliansyah (2013), who discussed the role of primary healthcare centers in providing the best possible service to patients. Syarif, Wahono, and Khoirul ABS (2017) found conditions related to facilities as being the most influential aspect of their performance from a patient perspective because these conditions indicated "assurance" that centers were able to provide the best possible health service. Meanwhile, inconvenient access may discourage people to seek treatment (Radito, 2014). Amenities in primary healthcare centers must be clean, tidy, and inviting so that more people will be willing to attend health check-ups and receive appropriate health treatment when sick. For those who live far away from treatment centers, mobile primary healthcare centers can be run more frequently, thereby ensuring that everyone receives appropriate health treatment.

Table 4. The financial circumstances of primary healthcare centers.

\begin{tabular}{|c|c|c|c|c|c|c|c|c|c|c|c|c|c|}
\hline & \multicolumn{3}{|c|}{ Bengkulu } & \multicolumn{3}{|c|}{ NTT } & \multicolumn{3}{|c|}{$\begin{array}{c}\text { South } \\
\text { Sulawesi }\end{array}$} & $\begin{array}{l}\text { Do not } \\
\text { know/Not } \\
\text { applicable }\end{array}$ & \multicolumn{3}{|c|}{ Total } \\
\hline \# Primary healthcare centers & \multicolumn{3}{|c|}{6} & \multicolumn{3}{|c|}{6} & \multicolumn{3}{|c|}{6} & & \multicolumn{3}{|c|}{18} \\
\hline Compared with 3 months ago & $<$ & $=$ & $>$ & $<$ & $=$ & $>$ & $<$ & $=$ & $>$ & & $<$ & $=$ & $>$ \\
\hline \multicolumn{14}{|l|}{ \# income } \\
\hline BOK fund & 0 & 1 & 4 & 0 & 0 & 6 & 0 & 1 & 4 & 2 & 0 & 2 & 14 \\
\hline JKN capitation fund & 1 & 2 & 1 & 1 & 1 & 2 & 0 & 1 & 3 & 6 & 2 & 4 & 6 \\
\hline General patients & 1 & 2 & 1 & 1 & 1 & 2 & 1 & 3 & 0 & 6 & 3 & 6 & 3 \\
\hline \multicolumn{14}{|l|}{ \# absorption of fund } \\
\hline BOK fund & 0 & 1 & 3 & 1 & 2 & 3 & 0 & 1 & 3 & 4 & 1 & 4 & 9 \\
\hline JKN capitation fund & 0 & 2 & 1 & 1 & 2 & 3 & 0 & 1 & 3 & 5 & 1 & 5 & 7 \\
\hline \multicolumn{14}{|l|}{ \# expenses } \\
\hline Medical service provision & 0 & 1 & 4 & 1 & 1 & 4 & 0 & 1 & 5 & 1 & 1 & 3 & 13 \\
\hline Health professionals & 0 & 2 & 3 & 1 & 2 & 2 & 1 & 0 & 2 & 5 & 2 & 4 & 7 \\
\hline Internal operations & 1 & 0 & 4 & 0 & 1 & 5 & 1 & 2 & 1 & 4 & 2 & 2 & 10 \\
\hline Outdoor activities & 0 & 1 & 4 & 0 & 1 & 4 & 0 & 1 & 4 & 3 & 0 & 3 & 12 \\
\hline Facility refurbishment & 0 & 1 & 1 & 2 & 0 & 1 & 0 & 0 & 1 & 14 & 0 & 1 & 3 \\
\hline
\end{tabular}

Note: the total number of primary healthcare centers may be less than 18 based on "not applicable" and "do not know" answers. "=" denotes did not change/remained stable; "<" denotes decreased minimally or significantly; ">" denotes increased minimally or significantly.

The absence of a doctor in primary healthcare centers may also demotivate people about pursuing healthcare. At the national level, there is an average of $1.83 \mathrm{GPs}$ and 0.73 dentists per primary healthcare center (Kurniawan, Yudianto, Hardhana, and Siswanti, 2018). In our sample, there were only 0.89 GPs and 0.39 dentists per primary healthcare center. This does not meet the standard minimum human resources for health in primary healthcare centers in remote and very remote areas set by the Ministry of Health (2014b). It also falls short of the number of GPs and dentists in primary healthcare centers in the city of Ambon, Maluku province, in Eastern Indonesia, which has had a GP and a dentist for the past 10 years (Corputty, Kusnanto and Lazuardi. Lutfan, 2013). Nurses and midwives sometimes serve as substitutes for doctors. There were more nurses and midwives per primary healthcare centers in our sample (an average of 17 nurses and 14 midwives) than was reported at the national-level (an average of 15 nurses and 12 midwives) (Kurniawan, Yudianto, Hardhana, and Siswanti, 2018). However, our sample was located in DTPK, where primary healthcare centers tend to have a (much) wider catchment area in Indonesia; hence, more nurses and midwives are needed to take up village health posts, or poskesdes, and village maternity clinics, or polindes.

In terms of activities, primary healthcare centers in our DTPK sample performed quite well, with a full range of indoor and outdoor activities including health education classes, outdoor detection of diseases in the community, and maintenance of active posyandu and posbindu. Outdoor activities in particular can enhance health service utilization, by informing more people about the availability of universal public health insurance and the wide variety of free health services available in primary healthcare centers (Restiyani, Fitriyah, and Astrika, 2013).

To ensure that DTPK communities have access to high-quality primary care, immediate policies can be directed to improve the available facilities in primary healthcare centers. Initially, this will involve liaising with the district health office to address access to primary healthcare centers and recruit GPs, and to provide laboratory technicians and pharmacists (Harian Nasional, 2017). As patient volumes increase, the health professional-to-patient ratio will decrease, which can harm the quality of services. Abdul Gani Hasan (2017) calculated that a shortage of doctors can see patients receive less than 
two minutes of consultation time. The local community may be able to help refurbish primary healthcare centers by coordinating actions together (gotong royong) for paving roads, repainting, and cleaning. To improve the quality of activities run by primary healthcare centers, creative and innovative educational programs must be designed. Moreover, managing poorly attended health education classes is a waste of resources. A small incentive (such as a souvenir) may be used to attract a wider audience in this regard. Primary healthcare centers can also liaise with the district health office to acquire additional resources (Listiana, Suryoputro, and Sriatmi, 2018). Health messages must also be conveyed simply and comprehensively to ensure that they can be implemented at home. Primary healthcare centers appear to have little incentive for upgrading their buildings. The researchers welcame the Ministry of Health's recent commitment to constructing more primary healthcare centers and renovating their existing run-down counterparts in DTPK before 2019 (Ramadhan, 2018).

In the long-term, policies should focus on the recruitment and retention of health personnel in DTPK. This should begin by cultivating altruism and morale among medical students serving in remote areas, and by providing incentives for medical graduates to work in DTPK. Attractive remuneration packages may also be designed to attract more experienced health personnel.

\section{CONCLUSION}

A primary healthcare center is where patients establish their first contact with a healthcare professional. As such, a primary healthcare center also presents opportunities for health personnel to detect diseases and provide appropriate health treatments to those who are sick or at high risk of developing health problems. The findings from our study revealed that primary care in primary healthcare centers in DTPK remains lacking, with inconvenient access to facilities and a lack of permanent doctors, pharmacists, and laboratory technicians. Nevertheless, primary healthcare centers have to date managed to handle the vast majority of patient presentations, which relate primarily to acute health complaints and non-communicable diseases. However, as disease profiles begin to shift towards primarily non-communicable diseases, primary healthcare centers may no longer be able to operate successfully without a permanent doctor. In terms of activities, primary healthcare centers in DTPK have been quite successful in interacting with their local communities through preventive and promotive programs. Finally, while primary healthcare centers received additional funding for catering to an increase in patient volume and daily operational activities, very few have used this opportunity to refurbish their facilities.

\section{CONFLICT OF INTEREST}

The authors declared no conflict of interest.

\section{REFERENCES}

Achdami, M. (2017) Libatkan Pemda Dalam Pembangunan Puskesmas, Harian Nasional. Available at: http://harnas.co/2017/08/24/libatkan-pemdadalam-pembangunan-puskesmas (Accessed: 20 November 2018).

Afifah, K. (2017) Hubungan mutu pelayanan kesehatan dengan minat kunjungan ulang pasien di puskesmas Cangkringan Sleman. Undergraduate Thesis. Sekolah Tinggi IImu Kesehatan Jenderal Achmad Yani Yogyakarta.

Alawi, M., Junadi, P. and Latifah, S. N. (2017) 'Analisis Faktor-Faktor yang Berhubungan dengan Tingginya Rujukan Kasus Non Spesialistik Pasien Jaminan Kesehatan Nasional pada Puskesmas di Kabupaten Sukabumi Tahun 2015', Jurnal Ekonomi Kesehatan Indonesia, 2(1), pp. 17-23. Available at: http://journal.fkm.ui.ac.id/jurnaleki/article/view/1954/645.

Apriyanto, D. (2015) 'Pengukuran Kinerja Puskesmas Dalam Rangka Peningkatan Layanan Kesehatan Masyarakat', Jurnal IImu Sosial, 14(2), pp. 46-62. doi: https://doi.org/10.14710/jis.14.2.2015.

Apriyanto, R. H., Kuntjoro, T. and Lazuardi, L. (2013) 'Implementasi Kebijakan Subsidi Pelayanan Kesehatan Dasar terhadap Kualitas Pelayanan Puskesmas di Kota Singkawang', Jurnal Kebijakan Kesehatan Indonesia, 2(4), pp. 180-188. doi: 10.22146/jkki.v2i4.3202.

Corputty, L. S., Kusnanto, H. and Lazuardi, L. (2013) 'Dampak Kebijakan Pelayanan Kesehatan Gratis Terhadap Kepuasan Pasien Dalam Menerima Pelayanan Kesehatan Puskesmas Di Kota Ambon', Jurnal Kebijakan Kesehatan Indonesia, 2(2), pp. 95-104. doi: 10.22146/jkki.v2i2.3220.

Djauhari, M. A. (2010) 'Pengaruh Implementasi Kebijakan Perimbangan Keuangan Terhadap Kualitas Pelayanan Puskesmas: Studi Kasus Kota Banjar Propinsi Jawa Barat', Sosiohumaniora, 12(1), pp. 25-38. doi: 10.24198/sosiohumaniora.v12i1.5438.

Eninurkhayatun, B., Suryoputro, A. and Fatmasari, E. Y. (2017) 'Analisis Tingkat Kepuasan Pasien Terhadap Kualitas Pelayanan Rawat Jalan di Puskesmas Duren dan Puskesmas Bergas Kabupaten Semarang Tahun 2017', Jurnal Kesehatan Masyarakat, 5(4), pp. 33-42. doi: https://ejournal3.undip.ac.id/index.php/jkm/arti cle/view/18314.

Firnanda N, Junaid and Jafriati (2017) 'Analisis spasial kejadian penyakit infeksi saluran pernapasan akut (ISPA) pada balita di kelurahan Puwatu tahun 2017', Jurnal IImiah Mahasiswa Kesehatan Masyarakat, 2(7), pp. 1-7. Available at: http://ojs.uho.ac.id/index.php/JIMKESMAS/art icle/view/3430/2585.

Gunawan, I. (2018) Penyakit ISPA Masih Jadi Penyakit Terbanyak di Wilayah Kecamatan Cikampek, Pojok Jabar. Available at: https://jabar.pojoksatu.id/pantura/2018/07/14/ 
penyakit-ispa-masih-jadi-penyakit-terbanyakdi-wilayah-kecamatan-cikampek/ (Accessed: 14 November 2018).

Hardhana, B., Yudianto and Soenardi, T. (2017) Data dan Informasi Profil Kesehatan Indonesia 2016, Pusat Data dan Informasi Kementerian Kesehatan RI. Jakarta. doi: 10.11607/ijp.4244.

Hasan, A. G. and Adisasmito, W. B. B. (2017) 'Analisis Kebijakan Pemanfaatan Dana Kapitasi JKN Pada FKTP Puskesmas Di Kabupaten Bogor Tahun 2016', Jurnal Kebijakan Kesehatan Indonesia, 6(3), pp. 127-137. doi: 10.22146/jkki.v6i3.29658.

Husain, I. (2006) Kualitas dan Kuantitas Tenaga Kesehatan Puskesmas, Studi Distribusi DesaKota dan Regional Analisis Data SAKERTI 2000. Available at: http://kebijakankesehatanindonesia.net/sites/ default/files/file/SDM/Artikel/--

Kualitas_dan_Kuantitas_Tenaga_Kesehatan_ Puskesmas.pdf.

Institute for Health Metrics and Evaluation (2018) 'New study: Indonesia faces a "double burden" of persistent communicable diseases and increasing non-communicable diseases', IHME Measuring What Matters. Available at: https://www.eurekalert.org/pub_releases/201 8-06/ifhm-nsi062718.php (Accessed: 15 August 2018).

Juliansyah, E. (2012) 'Efektivitas Pelayanan Kesehatan Di Puskesmas', JIANA ( Jurnal Ilmu Administrasi Negara ), 12(1), pp. 40-50. Available at: https://ejournal.unri.ac.id/index.php/JIANA/iss ue/view/117

KOMPAK (2017) 'Kondisi Pembiayaan dan Tantangan Sumber Daya Manusia Saat ini di Puskesmas', Ringkasan Kebijakan. Available at:

http://kompak.or.id/userfiles/publication/report /brief-puskesmas-11291.pdf.

Kurniawan, R. et al. (2018) Profil Kesehatan Indonesia Tahun 2017. Jakarta. Available at: http://www.depkes.go.id/resources/download/ pusdatin/profil-kesehatan-indonesia/profilkesehatan-indonesia-2017.pdf.

Listiana, N., Suryoputro, A. and Sriatmi, A. (2018) 'Analisis Penyebab Rendahnya Kinerja Organisasi di Puskesmas Candilama Kota Semarang', Jurnal Kesehatan Masyarakat (ejournal), 6(1), pp. 49-56. Available at: https://ejournal3.undip.ac.id/index.php/jkm/arti cle/viewFile/19833/18751.

Indonesian Ministry of Health (2014) Profil Kesehatan Indonesia Tahun 2013. Jakarta. Available at: http://www.depkes.go.id/resources/download/ pusdatin/profil-kesehatan-indonesia/profilkesehatan-indonesia-2013.pdf.

Ministry of Health of the Republic Indonesia (2014a) Profil Kesehatan Indonesia Tahun 2013. Jakarta. Available at: http://www.depkes.go.id/resources/download/ pusdatin/profil-kesehatan-indonesia/profilkesehatan-indonesia-2013.pdf.

Ministry of Health of the Republic Indonesia (2014b) Standar Ketenagaan Puskesmas Permenkes
75 Tahun 2014. Jakarta. Available at: https://www.scribd.com/doc/289645780/Stand ar-Ketenagaan-Puskesmas-Permenkes.

Ministry of Health of the Republic Indonesia (2017a) Data dan Informasi Profil Kesehatan Indonesia 2016, Kementerian Kesehatan RI. doi: $10.11607 /$ ijp. 4244.

Ministry of Health of the Republic Indonesia (2017b) Data Dasar Puskesmas Bengkulu 2016. Jakarta. Available at: http://www.depkes.go.id/resources/download/ pusdatin/data-dasar-puskesmas/2016/07. Data Dasar Puskesmas Bengkulu 2016.pdf

Ministry of Health of the Republic Indonesia (2017c) Data Dasar Puskesmas NTT 2016. Jakarta. Available at: http://www.depkes.go.id/resources/download/ pusdatin/data-dasar-Puskesmas/2016/19. Data Dasar Puskesmas NTT 2016.pdf.

Ministry of Health of the Republic Indonesia (2017d) Data Dasar Puskesmas Sulawesi Selatan 2016. Jakarta. Available at: http://www.depkes.go.id/resources/download/ pusdatin/data-dasar-puskesmas/2016/27. Data Dasar Puskesmas Sulsel 2016.pdf.

Ministry of Health of the Republic Indonesia (2018) Profil Kesehatan Indonesia Tahun 2017. Jakarta. Available at: http://www.depkes.go.id/resources/download/ pusdatin/profil-kesehatan-indonesia/profilkesehatan-indonesia-2017.pdf.

Napirah, M. R., Rahman, A. and Tony, A. (2016) 'Faktor-Faktor Yang Berhubungan Dengan Pemanfaatan Pelayanan Kesehatan Di Wilayah Kerja Puskesmas Tambarana Kecamatan Poso Pesisir Utara Kabupaten Poso', Jurnal Pengembangan Kota, 4(1), pp. 29-39. doi: 10.14710/jpk.4.1.29-39.

Nugroho P, Pramono LA and Mihardja L (2015) 'Hypertension and Kidney Dysfunction in Adult Population in Indonesia', Journal of Hypertension, 33, p. e43. doi: 10.1097/01.hjh.0000469882.58487.af.

PT Iconesia Solusi Prioritas (2017) Laporan Survei Kepuasan Masyarakat Terhadap Pelayanan Kesehatan Kota Surabaya Tahun 2016. Surabaya. Available at: http://organisasi.surabaya.go.id/home/file/pel ayanan publik/Laporan IKM Kesehatan 2017.pdf.

Putra, T. W. (2012) Implementasi Program Kesehatan Gratis (Studi Kasus Puskesmas Batua Makassar). Hasanudin University. Available at:

http://repository.unhas.ac.id/handle/12345678 9/1745.

Radito, T. (2014) 'Analisis Pengaruh Kualitas Pelayanan Dan Fasilitas Kesehatan Terhadap Kepuasan Pasien Puskesmas', Jurnal IImu Manajemen, 11(2), pp. 1-26. doi: 10.21831/jim.v11i2.11753.

Rahmayanti, N. S. and Ariguntar, T. (2017) 'Karakteristik Responden dalam Penggunaan Jaminan Kesehatan Pada Era BPJS di Puskesmas Cisoka Kabupaten Tangerang Januari-Agustus 2015', Jurnal 
Medicoeticolegal dan Manajemen Rumah Sakit, 6(1), pp. 61-65. doi: 10.18196/jmmr.6128.

Ramadhan, A. (2018) 260 Puskesmas berstandar nasional akan dibangun pemerintah., Antara Sumbar. Available at: https://sumbar.antaranews.com/berita/224291 /260-puskesmas-berstandar-nasional-akandibangun-pemerintah (Accessed: 4 November 2018).

Ramdani, A. H., Setiawati, E. P. and Herawati, D. M. D. (2016) 'Persepsi Dokter Puskesmas di Kota Bandung terhadap Implementasi Sistem Jaminan Kesehatan Nasional', Jurnal Sistem Kesehatan, 1(4), pp. 171-178. doi: https://doi.org/10.24198/jsk.v1i4.12804.

Restiyani, P., Fitriyah and Astrika, L. (2013) 'Aksesibilitas masyarakat miskin dalam memperoleh pelayanan kesehatan (Studi Kasus di Kawasan Kampung Tambak Mulyo Kelurahan Tanjung Mas Semarang)', Journal of Politic and Government Studies, 2(3), pp. 113. Available at: https://ejournal3.undip.ac.id/index.php/jpgs/ar ticle/view/2982.

Rizcarachmakurnia, N., Wigati, P. A. and Sriatmi, A. (2017) 'Analisis beban kerja dan kebutuhan tenaga perawat di Puskesmas Poncol Kota Semarang', Jurnal kesehatan masyarakat, 5(3), pp. 26-33. Available at: https://ejournal3.undip.ac.id/index.php/jkm/arti cle/view/17163.

Sagala, I., Trisnantoro, L. and Padmawati, R. S. (2016) 'The implementation of nhi policy by the public health care providers in the District of Anambas islands', Jurnal Kebijakan Kesehatan Indonesia, 5(3), pp. 115-121. doi: 10.22146/jkki.v5i3.30651.

Suharmiati, Handayani, L. and Kristiana, L. (2012) 'Faktor-Faktor Yang Mempengaruhi Keterjangkauan Pelayanan Kesehatan Di Puskesmas Daerah Terpencil Perbatasan Di Kabupaten Sambas (Studi Kasus Puskesmas
Sajingan Besar)', Buletin Penelitian Sistem Kesehatan, 15(3), pp. 223-231. Available at: http://ejournal.litbang.depkes.go.id/index.php/ hsr/article/view/2996.

Suharmiati, Laksono, A. D. and Astuti, W. D. (2013) 'Review Kebijakan tentang Pelayanan Kesehatan Puskesmas di Daerah Terpencil Perbatasan', Buletin Penelitian Sistem Kesehatan, 16(2), pp. 109-116. Available at: http://ejournal.litbang.depkes.go.id/index.php/ hsr/article/view/3299/3291.

Syarif, M., Wahono, B. and Khoirul ABS, M. (2017) 'Pengaruh mutu pelayanan terhadap tingkat kepuasan pasien (Studi kasus Puskesmas Kecamatan Pragaan Sumenep Jawa Timur)', Jurnal IImu Riset Manajemen, 6(5), pp. 34-50. Available at: http://riset.unisma.ac.id/index.php/jrm/article/v iew/502.

Utama, W., Lestari, W. and Ikmaluhakim, D. R. (2017) 'Pengukuran Kepuasan Pasien Terhadap Pelayanan Puskesmas Dengan Metode Servqual (Studi Kasus: Puskesmas Ngagel Rejo Surabaya)', in Proceeding SENDI_U. Available

at: https://www.unisbank.ac.id/ojs/index.php/sen di_u/article/view/5036.

Vondewi, R. (2010) Analisa Dan Perancangan Sistem Informasi Puskesmas (Studi Kasus: Puskesmas Rawat Inap Simpang Tiga Pekanbaru). Undergraduate Thesis. Universitas Islam Negeri Sultan Syarif Kasim Riau. Available at: http://repository.uinsuska.ac.id/372/1/2010_201102.pdf.

Worldbank (2018) Program for Results (PforR) Indonesia-Supporting Primary healthcare Reform -- I-SPHERE. Available at: http://documents.worldbank.org/curated/en/72 2581527068052303/Final-Technical-

Assessment-Indonesia-Supporting-PrimaryHealth-Care-Reform-P164277.docx. 